\title{
LAS LOGIAS MASÓNICAS. UNA SOCIABILIDAD PLURIFORMAL
}

por

\section{LUIS P. MARTÍN}

Université Blaise Pascal. Clermont-Ferrand II

RESUMEN: La Masonería, como prototipo de sociabilidad organizada por excelencia, se creó en torno a un espacio y no al revés; esta característica bace que la logia masónica sea la sede per natura de la sociabilidad de los masones. En este estudio, intentaremos explicar las diversidades que, desde el punto de vista de la sociabilidad, presenta una logia. Si bien estamos frente a una sociabilidad pluriformal, no debemos olvidar que también posee un marco normativo potente y estructurante que acompaña a la socialización. Si la logia es un espacio organizado, también tiene una funcionalidad múltiple (educativa, espiritual, cultural o politica), pero también es un lugar en donde el simbolismo elabora una apropiación del espacio y al que sólo se accede por medio de una serie de rituales fundamentalemente iniciáticos. La logia masónica tiene unos antecedentes culturales que predefinen un espacio social, y a su vez, estructura un tipo de sociabilidad múltiple en sus contenidos y plural en sus formas. En este trabajo vamos a abordar las sedes masónicas esencialmente bajo dos aspectos: su objeto y función y su utilización.

Palabras clave: España. Logias. Masonería. Siglos XIX y XX. Sociabilidad.

ABSTRACT: Freemasonry, as the prototype of organized sociability par excellence, was created around a space, and not the reverse, so that the lodge was by nature the ultimate seat of masonic sociability. In this study, we shall attempt to explain the diverse forms of the lodge, from the point of view of sociability. While we are examining a multifarious society, we should not forget that it also bas a powerful normative standard in regard to socialization. The lodge is an organized space, with multiple functions (educational, spiritual, cultural, political), but it is also a place in which symbolism appropriates that space, which can be entered only by means of a series of initiation rites. The masonic lodge bas cultural antecedents that predefine a social space and structure a kind of multiple sociability. In this article we will address the object, function and use of the masonic lodge.

KEY WORDS: Spain. Lodges. Freemasonry. Nineteenth century. Twentieth century. Sociability.

Hispania, LXIII/2, núm. 214 (2003) 523-550 
Cualquier modelo de sociabilidad configura un espacio que delimita sus actividades y es determinante en las sociabilidades formales y organizadas ${ }^{1}$. Sin embargo, en aquéllas que son espontáneas el espacio establece una relación más expresiva ya que se le recarga de una representación que compensa su falta de materialización física. Las sociabilidades sin espacio formalizador lo reducen en su funcionalidad y articulación, dispersan sus actividades y generan contradicciones en las relaciones. La Masonería, como prototipo de sociabilidad organizada, se creó en torno a un espacio y no al revés; esta característica hace que la logia masónica sea la sede natural de la sociabilidad de los masones.

Por otra parte, pocos espacios sociales han suscitado tanta polémica como las logias masónicas. El hecho de ser un espacio privado y reservado a sus miembros que prohiben el acceso a aquéllos que no son masones (o que no son invitados por la logia), ha motivado que se levantaran todo tipo de conjeturas, sospechas y rumores en torno a sus actividades. Si se le añadimos el famoso secreto masónico, tanto la Iglesia como algunas monarquías europeas del siglo XVIII no necesitaban otros argumentos para perseguir a la Masonería ${ }^{2}$. El secreto masónico tiene dos vertientes: la primera, que obliga a todo masón a no desvelar el contenido de las discusiones de la logia, manteniendo su privacidad; y la segunda, que lo considera como «un acto intransmisible» resultado de la suma de experiencias, saberes y conocimientos acumulados por un masón y que sólo le son útiles a él, luego «secretos». En este sentido, la Masonería es una sociedad que tiene secretos, pero no es una sociedad secreta.

Las primeras condenas a los masones recogían una gran variedad de acusaciones: complotar contra la Iglesia y los Estados, preparar acciones a nivel internacional dictadas por una tenebrosa e inexistente internacional masónica, ser lugares de lujuria, prostitución y de magia negra, etc. Todas contribuyeron a crear una imagen de las logias que alimentaron el antimasonismo católico y antiliberal. La conocida tesis contubernista, que el franquismo plasmó en la Ley de Represión de la Masonería y del Comunismo de 1940, representa la culminación jurídica de unas reacciones irracionales e ideológicamente orientadas. En este caso, las logias eran donde se "construía la anti-España», el sanctasanctorum de lo antiespañol y de la antipatria. Los preliminares de esta ley se encuentran en el expediente judicial de la logia «Helmántica» de Salamanca, y los realizó, en 1938, el catedrático de derecho penal de la Universidad de Salamanca, I. Tejerina ${ }^{3}$.

\footnotetext{
1 Ver MAURICE, Jacques: «Propuestas para una historia de la sociabilidad en la España contemporánea», Estudios de Historia Social, Madrid, n 50-51, 1989, p. 138.

2 Ferrer BenIMeli, José Antonio: La Masonería española en el siglo XVIII, Madrid, Siglo XXI Ed., 1986.

3 Ver MARTín, Luis P.: »La otra cara de la guerra civil: la represión de la Masonería salmantina», Salamanca, Revista de Estudios, Salamanca, n 40, 1997, pp. 431-445, y para la cuestión contubernista, FERrer BeNIMELI, José Antonio: El contubernio judeo-masónico comunista, Del satanismo al escándalo de la P-2, Madrid, Itsmo, 1982.
}

Hispania, LXIII/2, núm. 214 (2003) 523-550 
En este estudio, intentaremos explicar las diversidades que, desde la sociabilidad, presenta una logia. Si consideramos que la logia es una sociabilidad pluriformal es porque la logia es un espacio que posee un marco normativo potente y estructurante que acompaña a la socialización, que tiene una funcionalidad múltiple (es educativa, es espiritual, es cultural o política), pero que también es un lugar en donde el simbolismo elabora una apropiación del espacio y al que sólo se accede por medio de unos rituales. Por último, se debe tener presente que en la logia se practica una fraternización entre sus miembros que solidifica psicológicamente la pertenencia a esta sociabilidad. Es decir que la logia es ante todo una sociedad humana en donde, más allá de su función propia, se crean lazos, se fomentan amistades y se llevan a cabo actividades más lúdicas — como los ágapes- después de cada «tenida» (nombre que designa las reuniones de una logia.

La logia masónica tiene unos antecedentes culturales que predefinen un espacio social y, a su vez, estructuran un tipo de sociabilidad múltiple en sus contenidos y plural en sus formas. En este trabajo vamos a abordar las sedes masónicas bajo dos aspectos: su objeto y función y su utilización.

\section{LA LOGIA MASÓNICA Y SU CONSTITUCIÓN (HISTORIA Y FUNCIÓN)}

La Masonería es una sociedad que adoptó unos modelos de convivenvia social establecidos por los gremios de los canteros desde tiempos remotos. Estas reglas sociales se aplican tanto en las actividades como en los espacios de relación, confraternización y aprendizaje. Por esta razón, la logia masónica procede de una historia, de una tradición a la que se le otorgó un simbolismo y una función espiritual adoptada a los tiempos modernos.

El término "logia» es de origen anglosajón y designa un cuarto, una cabaña, un pequeño edificio. En los Old Charges o Antiguos Deberes de los masones operativos se menciona la palabra logia en no menos de 130 ocasiones desde la Edad Media. Este término se fue extendiendo en el mundo occidental y, en 1429 , en los archivos de priorato de Canterbury se cita a 16 masones de la logia» que, según sus costumbres profesionales, administraban libremente sus asuntos propios. Fueron los primeros reglamentos del oficio y definidos posteriormente en las primeras versiones de las Old Charges 4 .

En este espacio, los canteros trabajaban, comían y descansaban; era un espacio exclusivo y estaba regido por los maestros-canteros. Cuando los masones empezaron a utilizar este espacio en el siglo XVII, lo hicieron trazando simbólicamente en el suelo un rectángulo o posando una alfombra que representraba la logia. La apropiación de las logias fue progresiva a partir de esta época. Fue

4 DeLON, Francis: voz «Loge», en SAUNIER, Éric (Ed.): Encyclopédie de la Franc-Maşonnerie, Paris, Le Livre de Poche, 2000, pp. 507-508. 
un proceso lento. Comenzó cuando ciertos notables fueron invitados a las reuniones de las logias operativas al inicio de la decadencia del gremio de los canteros a mediados del siglo XVII.

En este contexto, se empezó a elaborar la primera transformación de un espacio "operativo" en un espacio "especulativo», que sólo fue posible por la introducción de una simbología que recogió fundamentalmente objetos, utensilios, metales y materiales de los canteros. No obstante, no se trataba aún de logias especulativas; más bien serían «asambleas fraternales» entre operativos y no-operativos ${ }^{5}$. En todo caso, esta evolución se produjo en pleno cambio cultural y sociológico en la Inglaterra post-revolucionaria y, sobre todo, a la llegada de los Hannover al trono. Las nuevas inquietudes socio-culturales de la aristocracia y de la nueva burguesía introdujeron nuevos modelos de sociabilidad cultural: los anticuarios de la Royal Society, auténticos historiadores y arqueólogos aficionados, recopilaron tratados de arquitectura antigua y medieval, colecciones sobre el hermetismo y la alquimia, estudios sobre el simbolismo, etc., que sirvieron para establecer el puente entre la Masonería operativa y la Masonería especulativa.

El carácter especulativo de la Masonería moderna al introducir los símbolos en su normativa hace de ellos una de sus ontologías más potentes: la de establecer su función social en base a una espiritualidad que emana de un conjunto de símbolos y que dan un «sentido» a su sociabilidad a la vez que «interpreta» una cosmogonía. Por lo tanto, los aspectos funcionales de las logias modernas se establecieron partiendo de los esquemas sociales originales de las "logias de los canteros", reelaborados por un grupo social que buscaba una sociabilidad «escogida y elevada» en la que el ocio no fuera únicamente una reunión de hombres en un club.

Ahora bien, la eclosión de logias en el siglo XVIII europeo se explica perfectamente por la existencia de un factor determinante: la utilización y ocupación de un nuevo espacio público, que es "comunicativo»; es decir, un espacio que genera las primeras manifestaciones de la opinión pública. Al mismo tiempo que las logias inician sus actividades por todo el continente europeo y americano, surgen todo tipo de sociedades: literarias, academias, clubs, salones, etc. Este ambiente favorece la fundación de logias; el desarrollo del comercio europeo y la progresiva hegemonía británica ayudaron a que la Masonería se exportara. Como vemos, la historia de la logia está íntimamente ligada a la evolución de modelos de sociabilidad aparecidos en Europa entre los siglos XVII y XX'

Aunque existen distintas definiciones del término «logia», desde el siglo XVIII todas apuntan hacia un mismo aspecto: la logia «es el local donde los

\footnotetext{
5 Beaurepaire, Pierre-Yves: La République universelle des francs-maçons. De Newton à Metternich, Rennes, Editions Ouest-France, 1999, pp. 49-51.

6 Ver HABERMAS, Jürgen: L'espace public. Archéologie de la publicité comme dimension constitutive de la société bourgeoise, Paris, Payot, 1993 [1 $1^{\text {a }}$ ed., 1962].
}

Hispania, LXIII/2, núm. 214 (2003) 523-550 
francmasones celebran sus asambleas o trabajos»' . En las constituciones de Anderson de 1723 se añade que también es aquel lugar en donde se realizan todas las asambleas masónicas. La logia es entonces el lugar por excelencia de la Masonería. En este espacio ya se delimitan varias funciones: no sólo es un lugar de reunión y de discusión, también es un lugar de «trabajo».

En efecto, el objetivo fundamental de la Masonería es «formar a los hombres», dentro de un método para el ser (es decir, para el hombre) y para estar en el mundo (es decir, para servir a la humanidad): una praxis que exige un trabajo interior e individual dentro de un grupo, pero que también es un trabajo colectivo. En este sentido se debe entender cuando se dice que la logia es un lugar de trabajo, y por esta razón se la reconoce como un «taller» en un perfecto continuum con las logias operativas. Así que cuando Muller analiza la función de la logia, revela este carácter laboral que aleja la Masonería de las sociabilidades de recreo:

\begin{abstract}
«La logia es un instituto práctico destinado no sólo a los amigos fieles que viven en sociedad, de conformidad con las reglas más perfectas de la vida social, sino que está especialmente dedicada a la educación de sus miembros, y a formarlos para el mundo y la humanidad. Las logias, son pues, en realidad verdaderos talleres en los cuales se trabaja para restituir al hombre al tipo primitivo alterado por circunstancias defavorables y por las tendencias separatistas de la sociedad»8.
\end{abstract}

Templo, taller, escuela... son denominaciones que explicitan y sintetizan la definición y la función de una logia. Por taller, se interpreta la renovación del hombre; por escuela, el aprendizaje; por templo masónico, la configuración simbólica y ritual que envuelve todo. Este es un concepto global de la logia que la proyecta como lugar de origen de la Masonería, y todo lo que resulta de la vida masónica es consecuencia de la logia. Tal posición espacial dentro de la sociabilidad masónica nos muestra claramente que la logia es algo más que un lugar de reunión; es, como indican los principios de la Franc-Masonería, un lugar de unión que conduce a la universalidad de la Orden. Cualesquieran que sean las situaciones, una logia particular respresenta una logia universal, en otras palabras, el mundo. Los masones lo explican manifestando su dedicación a la obra de la humanidad, de manera que «el universo no forma más que una sóla y única logia y los masones reunidos en su templo no son más que fracciones de la Logia Universal»?.

La intensidad del término, su impacto, sus referencias y su naturaleza misma, hacen que la Masonería no sepa desligar la logia de otras sedes masónicas que se reconocen en filiación directa con ella. Así, cuando a una logia se le aña-

7 Frau ABrines, Lorenzo y ARÚs ARDERÍUS, Rosendo: Diccionario Enciclopédico de la Masonería, México, 1976, p. 719.

8 Ibid., p. 720.

9 Ibid., p. 719. 
de un "capítulo» (taller masónico en donde se trabajan los grados superiores al tercero y que sirven de preparación para los grados filosóficos), la logia se denomina logia-capitular. Cuando a una logia se le adjunta un taller femenino, se llama logia de adopción (las primeras iniciaciones de mujeres se llevaron a cabo en España, en 1872, en las logias barcelonesas Silencio y Moralidad, auspiciadas al Gran Oriente de España. Esta obediencia intentó integrar la presencia femenina siguiendo una iniciativa de la logia Hijos del Trabajo de Madrid, que creó una logia femenina denominada Hijas del Sol ${ }^{10}$; cuando una logia genera otra logia, o la primera logia de un país o de un masón, se dice logia-madre; cuando una logia trabaja irregularmente, se le demonima logia irregular o salvaje; y por último, cuando se crea una estructura superior, el término que se emplea es el de Gran Logia. Se denomina Gran Logia a una federación de logias que aúnan sus objetivos y finalidades. Este organismo superior coordina las actividades de todas las logias, estableciendo unas normativas propias, tanto reglamentarias como legislativas. También se puede llamar Gran Oriente. A las dos apelaciones se les dice obediencia.

Aunque en la función de la logia se insista en el carácter formativo, éste no es el único. La logia contiene un sistema de interpretación simbólica y ritual (la logia también es una sociabilidad cultural), de interpretación ideológica (sociabilidad política), de convivialidad (sociabilidad recreativa), etc. La logia reúne estas realidades diferenciadas. Su poliformismo es, a la vez, una de sus originalidades y uno de los obstáculos para su comprensión, pero también uno de sus mayores atractivos. De aquí que la logia se la pueda considerar como un club de reflexión político, un centro filosófico, un laboratorio de ideas, una escuela o incluso un diner's club.

\section{ESPACIOS Y SÍMBOLOS}

Una logia tiene varios espacios que corresponden a un concepto preciso de su función y de los objetivos de la Masonería. El núcleo central es el templo, donde se celebran las tenidas. Tiene acceso por un pasillo o un vestíbulo denominado la sala de los pasos perdidos. En una zona apartada hay un gabinete de reflexión, donde el profano reflexiona y redacta su testamento masónico antes de su iniciación. La iniciación es un rito fundamental en la Masonería. El acto está repleto de toda la gravedad, intensidad, ceremonial y protocolo de un evento excepcional: el momento en que un profano se convierte en franc-masón, es decir que «abandona el mundo tenebroso y accede a la luz». Por lo tanto, la iniciación es un re-nacer, en el sentido de iniciar una nueva vida. En este sentido, la Masonería está más

10 Ver RANDOUYER, Françoise, «Presencia femenina precoz en las logias españolas (18681898)", en Ferrer BeNimeli, José Antonio (Ed.), La Masonería española en el 2000. Una revisión bistórica, Zaragoza, CEHME/Gobierno de Aragón, 2001, t. 2, p. 626.

Hispania, LXIII/2, núm. 214 (2003) 523-550 
próxima de las sociedades iniciáticas antiguas y orientales que de la sociabilidad burguesa contemporánea. Según la importancia de la logia, puede haber otras salas dedicadas a la biblioteca o a la secretaría.

El templo masónico tiene una configuración en donde ningún detalle es arbitrario. Su apelación indica el carácter sacralizador que se le otorga: es un templo presidido por el Gran Arquitecto del Universo, pero no es un lugar de culto. Los masones han elevado un templo en el seno de la logia porque recogen el ideal espiritual y comunitario del Templo de Salomón, eje central de la simbología masónica que hace referencia directa a los primeros constructores y, sobre todo, al arquitecto del templo de Jerusalén, Hiram. Los masones van a continuar el trabajo interrumpido por éste, dentro de una dimensión filosófica y ética, en el secreto y en el aislamiento del templo, trabajando «al resguardo de las intemperies», es decir, lejos de la curiosidad exterior de los profanos.

Todo templo masónico tiene forma rectangular, con una orientación «Oriente-Occidente». Por el Oriente penetra la luz que irradia el templo, donde se combate la ignorancia y la oscuridad; y por el Occidente se encuentra la puerta del templo que marca la frontera con el mundo profano, el mundo de las tinieblas. El masón, al penetrar en el templo, realiza un auténtico rito de transición al encaminarse de la oscuridad hacia la luz. Ya en su interior, se hallan dos columnas coronadas con dos granadas entreabiertas y cada una con la letra J y B: Jakin y Boaz; son las dos columnas de bronze del templo de Jerusalén que simbolizan el misterio de la generación, sostienen el templo y unen lo superior con lo inferior, lo celeste con lo terrenal.

En el centro del templo, siempre iluminado artificialmente, hay un pavimento formado por losas rectangulares negras y blancas como en un damero; es un espacio sagrado por donde no se puede caminar durante los trabajos. Este pavimiento simboliza la síntesis de los principios antagonistas pero complementarios; es decir, la coexistencia. Sobre él, se extiende el «cuadro de la logia» al inicio de las tenidas. Se trata de una alfombra que condensa los símbolos de un "grado» determinado, que deben servir al masón para reflexionar sobre los símbolos. La Masonería divide las diferentes etapas de acceso al conocimiento en grados.

Los tres primeros grados, simbólicos (la masonería azul), son los auténticos y son adoptados por todos los ritos; proceden de la masonería operativa: aprendiz $\left(1^{\circ}\right)$, compañero $\left(2^{\circ}\right)$ y maestro $\left(3^{\circ}\right)$. En el Rito Escocés Antiguo y Aceptado, los grados se distribuyen así: del $4^{\circ}$ al $18^{\circ}$, capitulares (la masonería roja), del $19^{\circ}$ al 30 , filosóficos (masonería negra) y del $31^{\circ}$ al $33^{\circ}$, sublimes (masonería blanca). La proliferación de grados que se dio a partir de finales del siglo XVIII hasta mediados del XIX tenía connotaciones herméticas, cabalísticas o caballerescas. A título de ejemplo, el Rito de Memphis, creado en 1839, tiene 92 grados y el Rito de Misraim (con el que se fusionó) 90 grados.

En torno al pavimento, hay tres candelabros situados en sus esquinas (excepto en la inferior izquierda) que simbolizan la Salud, la Belleza y la Sabiduría, que se encienden al comienzo de las tenidas y se apagan al finalizar éstas. En la parte 
superior de la alfombra, están posadas dos piedras, una bruta, simbolizando el estado simbólico del profano, y otra tallada, que es el fruto del trabajo - adquisición de la luz, del conocimiento...- que realiza cada masón en la logia. Las paredes están decoradas con objetos simbólicos y a menudo se cuelga una cuerda de doce nudos que rodea el templo simbolizando a la vez los lazos entre el cielo y la tierra, los doce signos del zodíaco o la «cadena de unión» (círculo que forman los miembros de la logia alrededor del pavimento, cogiéndose por el antebrazo —el derecho con el izquierdo-, con los brazos cruzados, símbolo de la fraternidad y de la cohesión de la logia); en cualquier caso, su función es la de mantener los distintos elementos contenidos en el templo, formando un todo homogéneo y armónico.

El techo del templo evoca la bóveda celeste, estrellada con numerosas constelaciones, símbolo del carácter cósmico y universal de la Masonería. En la pared del Oriente, la preside un triángulo equilátero, un delta luminoso, con un ojo en su interior - el ojo divino- que ve todo y simboliza la perfección del triángulo, símbolo de la unión de los contrastes y del número 3: los tres pilares que sostienen una logia (Fuerza, Belleza, Sabiduría).

Por último, entre la alfombra y la sede del venerable se encuentra el «altar» donde se depositan las «tres grandes luces» y donde se presta juramento ante la escuadra, el compás y el libro de la ley sagrada. La escuadra simboliza la regularidad y la perfección de los trabajos; el compás simboliza la búsqueda de la verdad, la prudencia, la justicia y la templanza; los libros sagrados: la Biblia, el Corán, un libro blanco, las Constituciones de la Masonería, una declaración de principios, etc. Esto demuestra la necesidad de establecer la tolerancia religiosa en la Masonería como un eje básico para la realización de la fraternidad. No obstante, la concordia fraternal no implica un franco desarrollo de la igualdad ${ }^{11}$.

La disposición de los masones en el templo obedece también a unas reglas precisas. El venerable maestro, que preside la logia y sus reuniones, se sitúa tras el altar, en el Oriente del templo; sobre su mesa dispone de un mallete (símbolo de la inteligencia), de un cincel y de una espada flamígera, que representa la llama interior de los masones, instrumento de transmisión con el que se inicia - a la manera de los ritos de caballería - a los masones. A su izquierda se encuentra el orador de la logia, que abre y cierra los trabajos, siendo el intérprete de la tradición masónica y haciendo respetar los reglamentos; y a la derecha del venerable, el secretario, que redacta las actas y lleva al día el «cuadro lógico» (conjunto de miembros que forman una logia) y la correspondencia. Los dos vigilantes, se sientan cerca de las columnas y de cara al Oriente. El vigilante primero se ocupa de la columna de los compañeros (a los que instruye) que se sientan en los asientos de la columna del Mediodía, y el vigilante segundo hace lo mismo con los aprendices que se sientan en la columna de Norte. Los maestros se instalan donde lo desean.

11 Ver Beaurepaire, Pierre-Yves: Franc-Maçonnerie et cosmopolitisme au Siècle des Lumières, Paris, Edimaf, 1998, pp. 58-90.

Hispania, LXIII/2, núm. 214 (2003) 523-550 
El espacio masónico está delimitado por una geometría y por unos símbolos, por una posición cósmica y una distribución humana, lo que produce una sociabilidad, no sólo formal y organizada, sino también diferenciada y original: a la vez espiritual, iniciática y ritual. Si este espacio se limitara a servir de escenografía, sólo sería la recreación de una sociabilidad paseísta y de ocio. Muy al contrario, este espacio tiene un sentido que viene dado por unas normativas sociales coherentes, que junto al uso de los rituales, construye una sociabilidad dinámica y plural ${ }^{12}$.

\section{ORIGEN, FUNDACIÓN E INSTALACIÓN DE LA LOGIA}

Una logia masónica nace por la voluntad de unos hombres, que ya son masones, y que desean levantar un taller propio. Es un acto colectivo que aúna intereses y objetivos comunes en torno a una actividad social precisa que saben está sometido a unas reglas de convivencia estrictas. La fundación de una logia suele estar razonada y, dentro del contexto español, suelen tener más importancia las razones ideológicas generales que una inquietud espiritual no declarada pero existente. La logia Reforma de Granada indica que su creación le vino inspirada por:

«los ideales de justicia, orden, moralidad, administración, democracia, reforma y progreso [...] por ser los que en breve tiempo han de regenerar la antigua y viciada masonería española, dándole el brillo, gloria y honor que le pertenece, y que le han de sacar victoriosa de las acechanzas que sus enemigos fraguan sin cesar en la sombra, valiéndose para ello de cuantos medios rastreros y solapados se pueden imaginar, con tal de destruirla y edificar en sus ruinas templos consagrados al error, tiranías, fanatismos, superesticiones y crímenes de toda especie»13.

Vasto programa de regeneración moral, social y anticlerical que se resume en lo que otras tantas logias españolas declaran como «la guerra al oscurantismo». Ahora bien, las actividades de una logia se explican a través de sus reglas; de su vida interna, de sus relaciones exteriores y de sus manifestaciones. Esta potente socialización viene enmarcada por unas estructuras sociales sólidas y por unos rituales, que también son un aspecto normativo que proyecta a toda la sociabilidad masónica un anclaje psicológico.

El proceso de constitución de una logia masónica se inicia con una primera tenida entre masones, en ejercicio o «durmientes» (todo masón que haya aban-

12 Ver BIAGgi, Vladimir: voz «Temple», en SAUNier, Eric (Ed.): Encyclopédie de la FrancMaçonnerie, op. cit., pp. 821-852, y sobre la decoración del templo y su simbología, NefONTAINE, Luc: Symboles et symbolismes dans la Franc-Maģonnerie, Bruxelles, Université Libre de Bruxelles, 1997, vol. 2, pp. 105-115.

13 Cit. por López CaSimiro, Francisco: Masones en Granada (último tercio del siglo XIX), Granada, Comares, 2000, p. 126. 
donado sus actividades masónicas, pero que ha cumplido los requisitos reglamentarios de su antigua logia; es decir, «estar a cubierto con el tesoro» o estar al día con las cotizaciones, o que no haya sido expulsado o «irradiado»), en la que cada uno presenta su diploma masónico o patente, una "plancha de quite» (certificado de baja de un masón en su logia de origen) con la que certifican estar en regla con su logia anterior. En esta reunión, se constituyen como «logia provisional» hasta obtener de una obediencia el reconocimiento, y se eligen los cargos y un presidente. En ocasiones, es el delegado de una obediencia el que oficia como presidente cuando en la localidad no hay un masón con suficiente antigüedad, como fue el caso en la logia Iris de Burgos en $1882^{14}$.

En una segunda reunión, los fundadores redactan un cuadro-lógico y hacen un borrador de su futuro reglamento. Una de las cuestiones debatidas en esta reunión es la elección del título de la logia. Los títulos son variados tanto dentro del simbolismo como en otros apartados. Su importancia es capital porque viene a ser la imagen del espírtu que sus fundadores quieren dar y representa una ideal común. Sobre este aspecto, las obediencias españolas adoptaron posturas diferentes. La mayoría establecieron una libre elección; sin embargo el Gran Oriente Nacional de España obligaba a sus logias a elegir un título original y distinto de logias ya fundadas ${ }^{15}$, lo cual no impide que nos encontremos con títulos idénticos en toda la geografía española.

En el estudio que realizamos para Castilla y León a finales del siglo XIX, relevamos ciertas particularidades. Un título bastante corriente era el de Igualdad (en Avila y Salamanca), el cual junto a otros como Fraternidad (Miranda de Ebro) y Libertad (Palencia) nos ofrece la triada republicana que inspiraba ideológicamente la mayoría de los masones. Otros títulos reflejan el racionalismo y el positivismo: Razón, Libertad, Deber (Salamanca), Progreso o Reforma (Valladolid), Aurora del Progreso (La Fuente de San Esteban, Salamanca) y Razón Libre (León) que conjugan inquietudes comunes a la gran familia de las heterodoxias españolas. Otros ejemplos son más explícitos, como el tratamiento que se da a la luz como elemento simbólico del trabajo masónico. Acoplar a la ciudad de la logia: Luz de León, Luz de Medina (Medina del Campo), Luz Bejarana; pero cuando ya se concibe como elemento del progreso humano, la logia se llama Electricidad (logia ambulante en la provincia de León en 1888).

En todo caso, excepto algunos títulos inspirados del mundo antiguo: Serapis (Salamanca), Legionense Apio Herdonio (León) y Minerva (Almazán), la mayoría hace referencia a la filiación directa con un personaje (Hijo y Hermanos de García Vao, Valladolid), con un símbolo (Hijos de la Luz, Alba de Tormes), de un todo (Hijos de la Humanidad, Salamanca) o de una virtud (Hijos de la Constancia, Astorga). Las virtudes son valores intrínsecos a la Masonería, pero también de una

14 Archivo General de la Guerra Civil Española, sección Masonería [en adelante AGGCEMas], leg. $\mathrm{n}^{\circ} 450 \mathrm{~A}$, exp. $\mathrm{n}^{\circ} 3$.

is Constituciones de la Franc-Masonería española y Leyes de la Institución, Madrid, 1893, p. 64. 
moral laica que reinserta su contenido en la sociedad y en oposición a la interpretación conservadora y católica: Entereza (Avila), Concordia (Burgos), Fortaleza (Valladolid), Tolerancia (Puebla de Sanabria -Zamora-), etc. ${ }^{16}$.

Por último, en una tercera reunión se procedía a la instalación de los cargos electos, se leía las actas de las tenidas precedentes y se enviaba una plancha (una carta) a la obediencia pidiendo oficialmente una carta constitutiva (carta-patente que certifica la regularidad de una logia auspiciada a una obediencia); a estos documentos, se añadían las cuotas que debían pagar los miembros de la logia a la obediencia ${ }^{17}$.

Como vemos, la fundación de una logia es un largo proceso, pero que no siempre aparece como estricto. Todos estos detalles muestran un carácter administrativo en la fundación de una logia que esconde una realidad menos burocrática, aunque en las planchas se leen en demasía términos de conveniencia y de fidelidad. Suelen ser por las actas de las tenidas en donde podemos palpar la voluntad de creación de la logia y sus motivos, como nos recordaba la logia granadina ya citada. Sin embargo, el medio geográfico también tiene una influencia decisiva en la fundación. La logia ambulante Electricidad de León declara que su objetivo es «reunir a varios hermanos que por sus trabajos en el mundo profano no pueden asistir a las tenidas masónicas» ${ }^{18}$. La originalidad extrema de este ejemplo revela cómo la masonería también es una sociabilidad que sabe adaptarse a los contextos más difíciles para realizar sus objetivos.

Una vez obtenida la patente, la logia puede preparar su instalación. Esta es una ceremonia que marca el nacimiento de una nueva vida en la que se desarrollará la sociabilidad masónica. Pero antes de alcanzar esta meta, los fundadores tienen que franquear otras barreras más materiales, como encontrar un local para instalarse. Este asunto fue uno de los problemas más serios a los que tuvo que enfrentarse la Masonería española. Disponer de un local, ya fuera en propiedad, en usufructo o en alquiler, condiciona toda instalación y determina la vida de la logia.

Sólo las logias socialmente más acomodadas podían tener una sede sin problemas de tesorería; el hecho de que la mayor parte vivieran en una debilidad económica crónica, hizo que el problema del local fuera endémico. Ahora bien, hubo otros aspectos interesantes, como la negativa de los propietarios de los inmuebles a alquilarlos para que "se hospede» una logia. Este rechazo obligaba a algunas de ellas a deambular entre las viviendas de sus miembros, cambiando de dirección e incomodidando las actividades, como fue el caso de la logia $\mathrm{La}$ Mirobrigense de Ciudad Rodrigo que cambió tres veces de sede en menos de tres años o la logia Hiram de Barco de Avila, confinada en un cuarto de la casa del

16 Martín, Luis P.: La Masonería en Castilla y León en el siglo XIX, Salamanca, Diputación Provincial de Salamanca, 1996, pp. 55-56.

17 Constituciones de la Franc-Masonería, op. cit., 1893, p. 64.

18 Reglamento Interior de la logia Electricidad, art. 1 (AGGCE-Mas, leg. $\mathrm{n}^{\circ} 360 \mathrm{~A}$, exp. $\mathrm{n}^{\circ} 18$ ). 
venerable, porque de esta manera se protegían del chismorreo y de la hostilidad local. Otros casos fueron más graves. Un miembro de la logia Fraternidad de Miranda de Ebro que cedía su piso, perdió su empleo obligando a la logia a pedir ayuda a la solidaridad masónica nacional para evitar la disolución. Otros casos muestran el detestable ambiente masónico local: en Valladolid, la logia Reforma, propietaria de un templo no lo cedió a la logia Fortaleza, taller que se separó de la primera y que trabajaba en otra obediencia; sin embargo, no opuso ninguna obstrucción a la logia Progreso, que pertenecía a su misma obediencia.

En suma, el local es fundamental en el desarrollo de la sociabilidad masónica y disponer de una sede provisional puede neutralizar sus actividades. Pero también una gran número de miembros puede colapsarla. ¿Cómo llevar a cabo tenidas en un templo cuando la logia tiene más de setenta miembros? Esto le pasó a la logia Hijos de la Humanidad de Salamanca, y era muy corriente en logias importantes. Sin hablar de la discreción. Imaginarse cincuenta o setenta masones encaminándose hacia una logia en una ciudad, de apenas veinte mil almas como Salamanca, que además era un auténtico nido de clérigos... ilustra perfectamente las dificultades que impone el medio social y urbano a finales del siglo XIX español. Los masones se debatían con elementos que, cotidianamente, les impedían ejercer su sociabilidad; ésto es algo que no se suele tener en consideración cuando también es un elemento clave en los análisis de toda sociabilidad ${ }^{19}$.

Resuelta la cuestión del local, se puede proceder a la instalación de la logia. En la reunión están presentes todos los fundadores y una comisión instaladora (un venerable y dos vigilantes) enviada por la obediencia, que preside el acto. A este evento se suelen invitar a otros masones para darle un mayor realce al acto. El ritual de instalación sirve como normativa general y todas las logias deben respetarlo: los masones son recibidos por la comisión y el presidente ordena al maestro de ceremonias que la presente. A continuación, las dignidades de la logia se dirigen a la puerta del templo e invitan a la comisión a penetrar en él, siendo recibida con todos los honores, entregándole a su presidente el mallete. Acto seguido, se procede a la apertura de los trabajos para la instalación que consiste en la lectura de las patentes de la nueva logia y en el juramento de sus oficiales. El presidente hace lo mismo con los otros miembros utilizando la misma fórmula. Después de un elogio a la obediencia, se hace una alocución sobre los principios y fines de la Orden masónica y se declara, dando tres golpes de mallete, que va a instalar la logia, y, con otros tres golpes, la logia queda instalada. Después de formalizar los cargos, el presidente toma la palabra y lee un «trozo de arquitectura» (comunicación o ponencia de un miembro de la logia redactada por un miembro de la logia). Para concluir, se pasa «el tronco de la viuda» (caja donde los masones depositan sus donativos para la beneficencia) y finaliza la ceremonia. La solemnidad que se da al acto hace olvidar el

19 Martin, Luis P.: La Masonería en Castilla y León, op. cit., pp. 58-59. 
carácter festivo de la instalación. Para distender este ambiente, la nueva logia invita a la comisión e invitados a un banquete que libera la tensión y en donde se fraterniza con más comodidad ${ }^{20}$.

Otra ceremonia, pero que tiene un carácter más simbólico, es la inauguración de un templo masónico; que lógicamente es la continuación de la instalación de la logia. En este acto, igualmente breve, se resalta la función laboriosa del templo: «bienvenidos sean los que vienen al Templo para dar a la obra la última mano», dice el Ceremonial y concluye el venerable resumiendo la finalidad de esta fundación: «que de igual modo que esos perfumes volatilizados por el fuego material se elevan y embalsaman, el aire que nos rodea, logren las excelencias de los dignos miembros de la Orden, que a este Templo concurran, llevar en alas de la virtud y el progreso la Verdad y la Ciencia por todo el mundo conocido» ${ }^{21}$.

La Masonería afirma su diferencia con otros modelos de sociabilidad en la elección de sus fines y en los medios que se da para «construir el Templo». Si esta comunidad establece unas reglas es porque necesita que reine entre sus miembros la armonía y la concordia, único modo de «trabajar». La jerarquía y la estricta estructura y organización racionalizan al máximo las relaciones sociales; pero a su vez, estas normas facilitan el acceso de todos los miembros de la logia a participar en los objetivos de la Masonería, dentro de una libertad individual y colectiva. Los reglamentos de cada logia se basan en las Constituciones de Anderson, en los landmarks (serie de principios masónicos, adoptados en el siglo XVIII por la Gran Logia Unida de Inglaterra) y en las constituciones de su obediencia. Si las dos primeras recogen aspectos fundacionales, las segundas se adaptan a los tiempos que caracteriza la plasticidad social de la Masonería. Así, los reglamentos fueron abriendo cauces de participación y de expresión interna. Por esta razón, y en una misma época, podemos encontrar en los reglamentos detalles diferentes; lo cual revela las distintas sensibilidades masónicas existentes en España.

El reglamento establece las normas de la logia, pero además la representa en el mundo profano y a las autoridades civiles. En este aspecto, toda la legislación sobre el derecho de reunión tuvo una incidencia mayor en la sociabilidad masónica. Prácticamente hasta el Sexenio, las logias fueron ilegales. Desde 1868 hasta 1875, la Masonería entró en la legalidad; pero la Restauración impuso una legislación ambigua que se tradujo por una gran arbitrariedad. De hecho, hasta 1887 la Masonería fue tolerada pero no reconocida. La Ley de asociaciones de 1887 cubrió este vacío legal y las logias pudieron presentar sus

20 Acta de Instalación de la logia Aurora del Progreso, al Or. de La Fuente de San Esteban. 20 de julio de 1889 (AGGCE-Mas, leg. $\mathrm{n}^{\circ} 732 \mathrm{~A}$, exp. $\mathrm{n}^{\circ}$ 8).

21 Ver "Ceremonial para la Instalación de una logia», en CABALlero DE PUGA, Eduardo: $R i$ tual Escocés del Maestro franc-masón, seguido de la Historia de la Francmasonería y segunda parte de la Jurisprudencia Masónica, Madrid, Tip. Dionisio de los Ríos, 1888. 
estatutos en los gobiernos civiles ${ }^{22}$. Para llevar a cabo esta gestión, las obediencias dictaron algunas disposiciones con el fin de evitar conflictos, imponiendo a las logias su aprobación del reglamento. Otras veces, algunos gobernadores civiles, en un exceso de celo, bloquearon la autorización obligando a las logias a pedir a las obediencias que resolvieran su caso en Madrid. Fue un asurito corriente y no deja de resultar extraña la actitud de estos gobernadores porque los reglamentos no contenían ningún aspecto político o religioso chocante. No obstante, el Gran Oriente Español en 1889 redactó un reglamento-tipo que impuso a sus logias, para eludir este espinoso asunto con los gobernadores civiles. El resto de las obediencias masónicas daba libertad a las logias para redactar su reglemento interno, que, por lo general, era copiado de otra logia, modificando solamente pequeños detalles.

Todos los reglamentos tienen una estructura uniforme que se presenta sin variaciones en la exposición de los capítulos, artículos y párrafos. Las logias permutan rara vez el orden y todos los objetivos de la sociedad masónica están claramente expuestos. Los reglamentos se abren con una declaración de principios que mencionan el título de la logia, la obediencia en la que se auspician y el rito que se practicará. Sigue todo un articulado que regula la vida de la logia: derechos y deberes de los miembros, cantidad y calidad de sus dirigentes, así como modo de su elección.

Un apartado importante es el que aborda las reglas de comportamiento colectivo e individual durante los trabajos, así como la gestión financiera o contable. Este articulado se completa con asuntos específicos como la beneficencia o los visitadores. Algunas logias añaden disposiciones sobre las condiciones para ser iniciado, la promoción de grados, las afiliaciones, los deberes hacia los hermanos enfermos o fallecidos. En la parte final de los reglamentos, se abordan aspectos administrativos: comisiones, secciones, ley penal y de justicia, y disposiciones generales o transitorias que solventarán asuntos puntuales o imprevistos. En general, los textos son minuciosos resaltando el carácter normativo y funcional; subrayan tanto la socialización inherente a la logia como una ordenada administración. No obstante, cada logia es libre de plasmar aspectos que otra sólo evoca de pasada. Así, la logia Reforma de Valladolid confeccionó un reglamento corto: nueve capítulos más uno provisional; sin embargo, la logia Luz de León, con un texto similar le añade un apéndice de cuatro artículos suplementarios. Al revés, la logia Hijos de la Humanidad de Salamanca, en quince breves capítulos aborda todos los aspectos reglamentarios.

22 Hidalgo Nieto, Ma ${ }^{\text {a }}$ Victoria: «Masonería y libertad de asociación», en FerRer Benimeli, José Antonio (Ed.): La Masonería en la España del siglo XIX, Valladolid, Junta de Castilla y León, 1987, vol. 2, pp. 409-409.

Hispania, LXIII/2, núm. 214 (2003) \$23-550 


\section{LA VIDA INTERNA DE UNA LOGIA}

La sociedad masónica genera una sociabilidad organizada y reglamentada, y las actividades que se llevan en su seno comportan distintas manifestaciones. En el interior del templo, la logia funciona de la manera que sus rituales y sus reglamentos le imponen, sin olvidar el carácter fraternal existente. La convivialidad y armonía también resultan de estas condiciones; de hecho, son un intento de encontrar un equilibrio social potente que facilite los trabajos masónicos.

Una tenida es una reunión de trabajo en una logia. Es cuando los masones debaten, reflexionan, hacen propuestas, eliguen sus cargos, votan, etc. Todo esto se concentra en una tenida y por lo tanto no pueden ser espontáneas y son convocadas. Existen diversos tipos de tenida: la ordinaria, la extraordinaria, blanca abierta (con invitados profanos pero el conferenciante es masón), blanca cerrada (el conferenciante es invitado y profano), tenida de duelo o negra, en honor de un hermano fallecido. Además, existen las tenidas de instrucción para cada grado en donde se estudia y reflexiona sobre los rituales y los contenidos de los mismos. Esta «unión fraternal» es a la vez una normativa y una voluntad común.

Cada logia establece la periodicidad de sus tenidas, pero sus miembros están siempre obligados a asistir. La ausencia debe ser siempre justificada, y las ausencias repetidas sin justificación son susceptibles de la irradiación. En regla general, y dependiendo del tamaño de las logias, las tenidas se llevan a cabo dos veces al mes. La mayoría de las logias de las capitales de provincia se establecen una vez por semana: la logia Hijos de la Humanidad de Salamanca se reunía todos los viernes, la logia Luz de León, los sábados; los masones de Burgos se reunían un día a la semana sin especificar y la logia Reforma de Valladolid celebraba sus tenidas todos los lunes.

El desarrollo de una tenida conoce varias fases. El venerable maestro lee la orden del día y las actas de la tenida anterior, por si cabe alguna discusión previa. A continuación se abren las discusiones, en las que hay un riguroso orden de turno de palabra. El exponente debe hacerlo sobre «el fondo del asunto»: el venerable puede, si hay divagaciones, retirarle la palabra. Si en los debates hay infracciones al reglamento, faltas a la conveniencia social o disgresiones, el venerable puede presentar una queja ante la comisión de justicia. Por lo tanto, los masones aprenden un comportamiento que exige el respeto y las buenas maneras: está prohibido contradecir o interrumpir al exponente; de esta manera, el derecho a la palabra está garantizado, aunque no de manera general: los aprendices no tienen durante el primer año derecho a la palabra, ya que están en periodo de aprendizaje, y tan sólo escuchan.

El papel del venerable es fundamental porque regula la fluidez de la discusión, la coordinación de los debates, así como vela por su ajuste legislativo. Al vigilar la armonía social, imprime una orientación al debate que lo «democratiza» por medio del uso del tiempo de palabra; de forma que los debates tienen un principio y un fin. Es de regla admitida que para un mismo asunto se pueda 
hacer dos exposiciones y la última para rectificar, si hay lugar. Toda discusión finaliza con una votación del tema tratado, sin justificación del voto, salvo si hay ofensa o perjuicio para un miembro de la logia. En definitiva, la utilización de la palabra entra dentro de un convenio social que el reglamento de la logia Progreso de Valladolid expone con sencillez:

«Todo obrero [masón] tiene el derecho de emitir libremente su pensamiento; pero siempre debe hacerlo con moderación, respetando las opiniones de los demás, acatando las decisiones de la mayoría y guardando las formas propias de un buen masón» 23 .

Una vez concluidos los asuntos del orden de la tenida, administrativos o instructivos, los masones pueden depositar en el saco de proposiciones todo tipo de demandas que serán estudiadas en las tenidas siguientes. Estas demandas pueden concernir la propuesta de iniciación de un profano, la lectura de un trabajo, la organización de un ciclo de conferencias o la denuncia de un asunto interno. A continuación, el hermano limosnero hace circular el saco de la beneficencia, en el que cada masón debe depositar una cantidad de dinero que se destinará a estos fines; este depósito es obligatorio, incluso para aquél que no está presente en la tenida. En este caso debe hacerlo llegar por el conducto que estime oportuno.

La tenida concluye con la formación de la cadena de unión y los golpes de mallete del venerable, tradicionalmente a medianoche. Acto seguido, los masones pasan a compartir un ágape, en donde la fraternización es más espontánea y libre y que muestra el carácter plural de la sociabilidad masónica.

La elección de cargos es un apartado importante si consideramos a la Masonería como «una escuela de formación del ciudadano». La práctica del voto supone debatir e implica a cada masón en el devenir de la logia. Se utilizan tanto el voto secreto como el voto a mano alzada, o declamando. Para cierto tipo de asuntos como las propuestas para iniciar a un profano, se vota con bolas: las bolas blancas, son aprobatorias y las negras son reprobatorias. El voto, siendo permanente, estimula el uso de la opinión, el contraste de pareceres y, en suma, desarrolla entre los masones un hábito de pàrticipación en la res-publica que necesariamente conduce a que en la Masonería española se desarrolle el hábito a debatir en público. Es inevitable que los debates en las logias y el constante recurso al voto crean un «espíritu democrático»; pero más allá de este dato, el ejercicio de la palabra, la lectura de conferencias y los debates, son ejercicios de formación para aquellos masones que se dediquen a la política ${ }^{24}$.

23 Reglamento Interior de la Resp. Logia Progreso, 1888, art. 25 (AGGCE, Mas., leg. $\mathrm{n}^{\circ} 730 \mathrm{~A}$ ).

24 Martín, Luis P.: «La logia y la tribuna. Los políticos masones de Castilla y León (18681900)", en FERRER BENIMELI José Antonio (Ed.): Masonería, revolución y reacción, Alicante, Instituto de Cultura Juan Gil-Albert, 1990, t. I, pp. 157-167.

Hispania, LXIII/2, núm. 214 (2003) 523-550 
Las elecciones se llevan a cabo, aunque caben excepciones, el mes de diciembre para desempeñar las funciones el año siguiente, y siempre antes del solsticio de invierno. Se suelen convocar con cuarenta y ocho horas de antelación y se realizan "en familia», es decir, con sólo los miembros de la logia. El voto es uninominal y secreto, llevándose un riguroso orden de votación. El primer vigilante pasa lista, por columna; los componentes de ésta se dirigen a la mesa del venerable y depositan el voto en una urna. Pasan a continuación los ocupantes de la otra columna. Por cada elector, el venerable declama: «el hermano X ha votado", y una vez finalizado el voto y clausuradas las elecciones para cada cargo se procede al escrutinio.

Cada obediencia tiene su concepto en cuanto a los votos exigidos para obtener el cargo. Para el Gran Oriente Nacional de España (de Pantoja), el candidato debe tener la mayoría absoluta; para las demás obediencias, les bastaba con la mayoría simple. Cuando no hay mayoría, se procede a una segunda votación, y a una tercera entre los candidatos con mayor número de votos. Para el escrutinio del cargo de venerable se dan algunas diferencias. El citado Gran Oriente Nacional de España obligaba que todo candidato fuera maestro-masón o grado superior, y de estos se proponía una lista cerrada de cinco miembros-candidatos al resto de la logia. Para este cargo, esta obediencia exigía la mayoría absoluta; en otras obediencias, los dos tercios. Cuando había litigio por igualdad de votos, y en caso de que llegue a un tercer escrutinio, se elegía venerable al masón con más grado y con mayor antigüedad en la Masonería. Al final del escrutinio, se leían los resultados, dando una batería (aplauso) a cada uno de los nuevos cargos y tres baterías al venerable, que tomaban posesión de ellos en la tenida siguiente. La actitud de esta obediencia venía justificada por las «circunstancias de cada país»; es decir, por una cultura política española poco acostumbrada a estos ejercicios democráticos según Eduardo Caballero de Puga ${ }^{25}$.

Las logias practicaban en las tenidas diversos trabajos. Los administrativos (finanzas del taller, correspondencia, secretaría) ocupaban un lugar importante dada la intensa burocracia masónica española. Por la secretaría de una logia pasaba de todo porque, desde las actas que redactaba el secretario en cada tenida hasta la carta que se enviaba a un miembro recalcitrante que no pagaba su cuota desde hacía meses, la secretaría era fundamental. Y las tareas de la secretaría llevaban a algunas logias a eximir el pago de la cuota mensual al secretario y en algún caso se preveía una pequeña remuneración, aunque era una función benévola.

También cabe referirse a los trabajos relativos al personal, en donde se debatía sobre los candidatos que deseaban ingresar en la logia, bien sea para ser

25 Caballero de Puga, Eduardo: Ritual Escocés de las Grados Capitulares del cuarto al décimo octavo, o sea del Maestro Secreto al Príncipe Rosa Cruz, Madrid, Tip. Dionisio de los Ríos Díaz, 1889, pp. 259-260. Sobre las elecciones, ver Constituciones de la Masonería española del Serenísimo Gran Oriente Español y Ley de Tributación, Madrid, Imp. Moreno y Rojas, 1889, y GRAN ORIENTE NACIONAL DE ESPAÑA: Constitución de la Franc-Masonería española, Madrid, Imp. del Gran Oriente Nacional de España, 1884. 
iniciados en la Masonería o afiliados; también se resolvían, o se trataban, numerosos litigios que en ocasiones terminaban en la comisión de justicia que dirimía sobre el caso.

La propaganda masónica era uno de los trabajos más debatidos. La necesidad de aumentar la influencia masónica en la sociedad circundante para contrarrestar la propaganda de la Iglesia fue una preocupación constante de las logias; de aquí su interés por tener un órgano de prensa o colaborar con la prensa local. Aunque crear una revista resultaba muy difícil, la propaganda era transmitida por otros canales, personales o sociales, que paliaban la inexistencia de una prensa masónica local. A lo largo del siglo XIX, la publicística masónica fue importante en cantidad, pero débil en intensidad; siempre debido a escasas finanzas, pero también a que el público interesado por las revistas masónicas era muy reducido. La prensa masónica española tuvo un fuerte impulso en Cataluña, en el Levante y en Andalucía, debido a la importante implantación de la Masonería. Ahora bien, la presencia de masones en ateneos, casinos, centros de instrucción, laicos, etc., suplió con creces la débil propaganda de la orden.

Los trabajos fundamentales de las logias giraban en torno a la instrucción y a la adquisición de conocimientos. Las tenidas de instrucción, irregularmente llevadas a cabo en casi todas las logias españolas, tenían por objetivo en profundizar la filosofía y el simbolismo de los rituales del grado. En el grado de aprendiz, se realza la necesidad de la duda en el hombre, primer paso para la autonomía de la conciencia, como inicio del camino de la búsqueda de la verdad, estableciendo una comunicación con Dios, con la naturaleza y la sociedad y con su propia conciencia. En el grado de compañero, se busca la emancipación del hombre por el conocimiento, que será puesta en beneficio de la sociedad y que lo resume la máxima «Nada de lo que interesa a la Humanidad debe ser indiferente al hombre y por consiguiente al Francmasón». Para el grado de maestro, por el estudio de la filosofía y la teología, pero también de las ciencias, se aborda la transformación del cuerpo y la inmortalidad del alma.

Es decir, que en esta etapa el masón va adquiriendo todos los elementos formativos necesarios, entre ellos la moral, para comprender «racionalmente» la inmortalidad del alma, lo que significa «vencer la muerte». Los trabajos del grado de maestro son muy importantes en la vida de un masón, y más aún en la vida de un masón español ${ }^{26}$. El contexto ideológico y político incitaba constantemente a hacer una serie de interpretaciones que venían a explicar las diversas posturas de la Masonería; así, el materialismo de la Gran Logia Regional Catalana traducía una poderosa influencia del cientifismo o, en otras obediencias, el panteísmo se plasmaba por un mimetismo krausista o armoniscista ${ }^{27}$.

26 Sobre los rituales, ver Álvarez LÁzARo, Pedro: La masonería, escuela de formación del ciudadano. La educación interna de los masones españoles en el último tercio del siglo XIX, $2^{\mathrm{a}}$ ed., Madrid, Universidad Pontificia de Comillas, 1998, pp. 240-255.

27 Ureña, Enrique M.: «Krause y su ideal masónico: hacia la educación de la humanidad», Historia de la Educación, Salamanca, n²4, 1985, pp. 73-95.

Hispania, LXIII/2, núm. 214 (2003) 523-550 
Estas posturas se declinaban en un sinfín de tendencias: anticlericalismo rabioso $^{28}$, republicanismo radical ${ }^{29}$, materialismo social avanzado ${ }^{30}$, moderantismo reformista burgués...

Los grados superiores también tenían sus tenidas de instrucción en donde se trabajaban aspectos sociales que se traducían por la función del masón en la sociedad; lo que vendría a resultar una "formación del ciudadano» y un servidor de «la construcción de una sociedad democrática». Por otra parte, las logias organizaban conferencias, que en términos masónicos se denominan piezas de arquitectura, dadas libremente por algún miembro de la logia o invitado (profano o masón). Estas conferencias versaban tanto sobre aspectos simbólicos como esotéricos; pero eran los temas sociales, religiosos, culturales o políticos los que dominaban. Las obediencias solían establecer unos temas de reflexión que se tratarían en las logias con el fin de hacer una síntesis y tener conocimiento de la sensibilización o actitud de los masones sobre el o los temas propuestos. En 1894, el Gran Oriente Español lanzó una encuesta sobre las órdenes religiosas en España que dio lugar a un gran debate en las logias y a la exposición de estudios y conferencias sobre la cuestión, que fueron abordados desde distintas perspectivas (religiosas, culturales, históricas, sociales o políticas).

Las logias tenían, por su parte, toda la libertad de desarrollar estos u otros trabajos. Al final de las tenidas, los masones podían depositar en el saco de proposiciones el tema de una pieza de arquitectura que se leería, si fuese aprobado por la asamblea, en una tenida: Este sistema de trabajo completaba las tenidas de instrucción que eran las más corrientes, lo que provocaba una escasez de estas piezas de arquitectura, convirtiendo las logias en meros "centros de instrucción" masónicos, limitando los debates y haciendo de las logias un espacio de adoctrinamiento, muy lejos de la función original de la Masonería. No obstante, teniendo en cuenta el ambiente ideológico en la España de la Restauración, las logias podían darle a sus trabajos una orientación que no obligatoriamente sería doctrinal.

La gran cantidad de aspectos reglamentarios que protegían las logias con el fin de alcanzar sus fines producía una serie de conflictos que, sin duda, solían perturbar seriamente la sociabilidad masónica. Podríamos señalar varios tipos de problemas internos haciendo una distinción neta entre los problemas individuales de los colectivos. De los individuales, el más corriente era el absentismo, primer signo de una defección que casi nunca declaraba el escaso interés o frustración que sintieron algunos masones de lo que se hacía en las logias. Este abandono se manifestaba por una morosidad en las cuotas mensuales y nos

28 Álvarez Lázaro, Pedro: «Las Cámaras Giordano Bruno: un paradigma de anticlericalismo masónico decimonónico", en Masonería, política y sociedad, op. cit., t. 2, pp. 791-808.

29 LÁZARO LORENTE, Luis: «Blasco Ibáñez, masonería, librepensamiento, republicanismo y educación», en FERRER BENIMELI, José Antonio (Ed.): Masonería, revolución y reacción, op. cit., t. 1, pp. 213-226.

30 SÁNCHEZ I Ferré, Pere: La Mą̧oneria a Catalunya, 1868-1936, Barcelona, Edicions 62, 1990 , pp. 261-277.

Hispania, LXIII/2, núm. 214 (2003) 523-550 
encontramos con el caso tipificado de «irradiado por falta de asistencia y pago». Los pocos masones que evitaron in extremis esta expulsión justificaron su estado personal o profesional que les impedía ejercer como «buenos masones», pese a que siempre existían maneras de comunicar la ausencia prolongada, como fue el caso de algunos militares. En nuestros estudios, nos hemos topado con casos de expulsión dolorosos: como la de un masón vallisoletano que por golpear a su esposa fue declarado indigno de ser masón y expulsado de su logia, como sucedió en la logia Hijos de García Vao, en $1888^{31}$. Una buena conducta social y una reputación sin tacha eran exigidas por todos los reglamentos de las obediencias y de los talleres. La mínima falta cometida por un masón se consideraba como un atentado a la misma Masonería: los diarios neo-católicos y anti-masónicos no se privaban de darles publicidad, ridiculizando, de paso, la probidad moral de la Masonería.

Los conflictos colectivos se generaban por razones diversas. La más común fue la oposición entre dos grupos que se acusaban mutuamente de algún error o falta. Muchos de estos mostraban una disconformidad con la dirección de la logia; ya fuera porque al equipo dirigente se le acusaba de actuar de forma autoritaria, ya fuera porque se enfrentaban dos interpretaciones distintas de lo que era la Masonería. Estos conflictos fueron graves, bastante corrientes e hicieron un mal incorregible a la expansión de la sociedad masónica. Un primer ejemplo sucedió en Valladolid con la logia Reforma, produciéndose una escisión con la formación de dos logias. En el segundo caso, la unión del Gran Oriente Nacional de España dirigido por el vizconde de Ros y de un grupo del Gran Oriente de España, dirigidos por Miguel Morayta en 1888, produjo un sinfín de escisiones, separaciones de logias y creaciones de nuevas, en toda España.

Este hecho manifiesta claramente que se trataba de conflictos producidos porque no existía una idea única de lo que era la Masonería y muestra la pluralidad masónica que siempre hubo en España. Al margen de estos casos, hubo otros conflictos que provocaban gravísimas situaciones: la desaparición de fondos del tesoro de la logia, la falsificación de actas y hasta peleas, que traían como corolario la clausura de la logia, a no ser que la obediencia tutelar impusiera el orden y expulsara a los culpables de tales faltas. Este caso tuvo lugar en la logia Francisco Arouet de Voltaire de Ferrol en septiembre de 1893, y ha sido de calificado de "escándalo tabernario y ópera bufa» ${ }^{32}$.

Tanto unos conflictos como otros nos muestran la dificultad con que se lograba la armonía en las logias. La Masonería obligaba a sus miembros a insertarse en una socialización potente, acatando una autoridad presidencial (el venerable maestro) con un real poder de control, aceptando la regulación de los debates y de la organización estricta de las logias. De esta forma comprende-

31 AGGCE-Mas., leg. $\mathrm{n}^{0} \cdot 730 \mathrm{~A}$, exp. $\mathrm{n}^{\circ} 7$.

32 VALín FernándeZ, Alberto: Galicia y la Masonería en el siglo XIX, A Coruña, Ediciós do Castro, 1990, pp. 264-265.

Hispania, LXIII/2, núm. 214 (2003) 523-550 
mos porqué el código de justicia del Gran Oriente Nacional de España de 1890 (rama de Eduardo Caballero de Puga y José Pantoja) tenía «sólo» 141 artículos y la ley de enjuiciamiento, 328 artículos.

\section{LAS RELACIONES EXTERIORES}

No se puede entender lo qué es la Masonería sin penetrar en el complejo entramado de sus relaciones. Al adjetivarlas de exteriores debemos puntualizar que son exteriores a la vida interna de la logia, porque en nada son extrañas a la vida de una logia. La Masonería, al estructurarse en obediencias, establece una serie de relaciones que consolidan las logias. Esta asociación extendida a un territorio (local, regional o nacional) establece vínculos de interés común que son fraternales y burocráticos. La organización piramidal de las obediencias también favorece un desarrollo de las relaciones exteriores así como el mantenimiento de una correspondencia y una circulación de los boletines u otras revistas masónicas. Todo este andamiaje bien puede denominarse «redes» y como tales se puede entender la Masonería. En definitiva, la sociabilidad masónica también es visible por las redes que construye; lo que le da otra característica propia y diferente de otros modelos de sociabilidad 33 .

Las relaciones «exteriores» comienzan con la demanda de creación de una logia, que se hace por el conducto de una obediencia; luego, la célula masónica resulta de un reconocimiento «exterior» a la sociabilidad que se desea crear. La obediencia actúa por medio de otras logias locales o regionales que son las que van a instalar la nueva logia; luego, le dan visos de normalidad institucional y carta social de actividad. A partir de la segunda mitad de la década de los años 80 del siglo XIX, se produjo en toda España una expansión sin precedentes de la Masonería que multiplicó las actividades exteriores de las logias. Así, la logia Hijos de la Humanidad de Salamanca ejerció de «instaladora de logias» de la provincia entre 1887 y 1891: las logias de Béjar, Ciudad Rodrigo y Alba de Tormes fueron «hijas» de la logia capitalina ${ }^{34}$.

A continuación, la nueva logia establece contactos con otras intercambiando garantes de amistad (miembro de la logia, escogido por una logia de otra localidad, que le representa en su nombre); se acogen hermanos visitadores y se participa a la vida masónica local con otras logias; se forman capítulos u otros organismos masónicos superiores. La Masonería tiene otras sedes que la logia en donde se trabajan los grados superiores a los simbólicos. El capítulo (del $4^{\circ}$ grado al $18^{\circ}$ ), el Aerópago del Kadosch (del grado $19^{\circ}$ al $30^{\circ}$ ), el Tribunal de

33 Sobre la funcionalidad de las redes sociales, ver DIANI, Mario: «Las redes de los movimientos: una perspectiva de análisis», en IBARRA, P. y TejerinA, B. (Eds.): Los movimientos sociales. Transformaciones políticas y cambio cultural, Madrid, Trotta, 1998, pp. 243-270.

34 MARTíN, Luis P.: La Masonería en Castilla y León, op. cit. 
Grandes Jueces Comendadores (el $31^{\circ}$ ), el Consistorio (el $32^{\circ}$ ) y el Supremo Consejo de Inspectores del grado 33 (el $33^{\circ}$ ). Todos ellos dentro del Rito Escocés Antiguo y Aceptado, el más utilizado en España. A través de todas estas actividades, una logia no es un espacio cerrado, sigue siendo discreto, pero está abierto a su mundo sin el cual apenas puede vivir, aunque una logia es siempre libre.

Estas relaciones en ocasiones eran la consecuencia forzada de factores ajenos a la logia. La excesiva cantidad de masones pertenecientes a la logia Reforma de Valladolid fue sin duda otra de las razones que la llevaron a dividirse. Esta escisión no supuso una merma de relaciones entre las logias; de igual manera cuando se practicaban fusiones de logias, solían servir a consolidar una sociabilidad masónica moribunda.

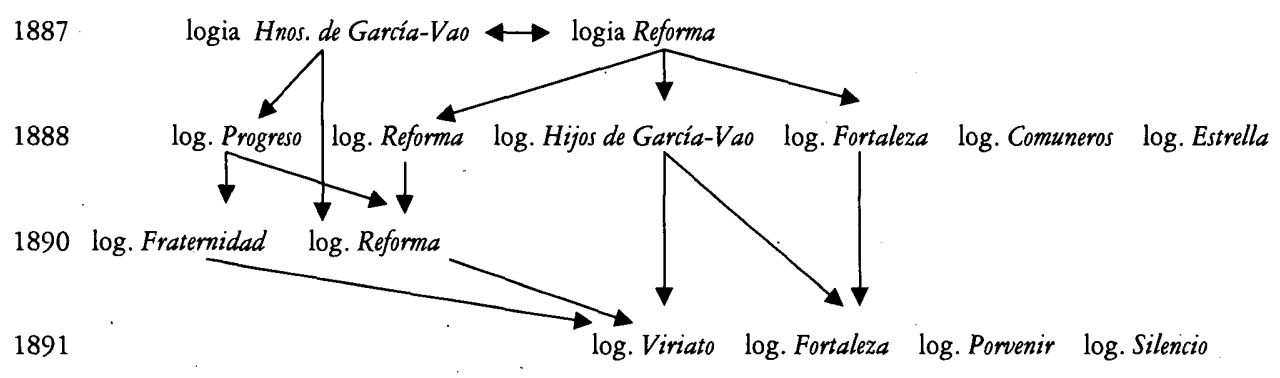

Si observamos los movimientos (desplazamientos, fusiones y desapariciones) de las logias de Valladolid en la brevedad de cuatro años, la red masónica local respondía a los factores señalados, pero también al nuevo mapa masónico español que se instaló a partir de 1887 y hasta 1891. La Masonería española tuvo dos grandes obediencias (excepto el Gran Oriente Lusitano Unido, al que pertenecieron un importante número de logias españolas): el Gran Oriente Nacional de España (GONE) y el Gran Oriente de España (GODE). En 1887, un grupo del GONE, dirigido por el Vizconde de Ros, se separó manteniendo el mismo título. Por su parte, un sector del GODE, dirigido por Miguel Morayta, procedió a un intento de unión masónica nacional y, junto con el GONE de Ros, crearon en 1888 una obediencia bicefálica que se escindió en 1889. Los seguidores de Ros conservaron el nombre de GONE hasta 1893 que pasó a llamarse Gran Oriente Ibérico (GOIco). En cuanto al sector de Morayta, se denominó Gran Oriente Español (GOE), que fue la obediencia española más importante hasta la guerra civil. El GONE y el GODE originales continuaron su vida hasta 1896. Hubo otra obediencia importante, fundada en 1887: el Gran Consejo General Ibérico ${ }^{35}$.

35 Ver ÁlVArez LáZARO, Pedro: «Pluralismo masónico en España en el siglo XIX», en FerReR BeNIMELI, José Antonio (Ed.): La Masonería en la España del siglo XIX, op. cit., t. 1, pp. 19-55. 
Las relaciones entre las logias, en estos casos, eran malas y se produjeron rencillas y enemistades que nada tenían que ver con el ambiente local. En algunos casos, los desplazamientos de masones de una logia a otra responden a la búsqueda de una sociabilidad más adaptada a sus gustos (como en las logias Fortale$z a$ e Hijos de García-Vao). Lo curioso es que, en algunos casos, y al cabo de algunos años (caso de la logia Viriato), encontramos masones que transitaron por tres logias locales. En cuanto a las fusiones forzadas por las obediencias, solían traer malas sorpresas, como sucedió entre la logia Reforma y Fortaleza en 1895.

La influencia del contexto masónico nacional era evidente. Durante la dictadura de Primo de Rivera, se produjo una reorganización de las relaciones masónicas en Madrid, Levante Cataluña y Andalucía, con la finalidad de cerrar filas frente al régimen militar. Las redes masónicas pusieron en evidencia la flexibilidad de sus capacidades y, con el concurso de numerosos oponentes al régimen, se crearon nuevas logias sobre la base de las antiguas. Si en este marco lo que se denota es el carácter político de la sociabilidad masónica, en otras ocasiones la empatía partidista también facilitaba las relaciones entre logias, aunque no era una condición fundamental, menos evidente a finales del siglo XIX que en la segunda década del XX. Sobre la ocupación del espacio social y político, el ejemplo de Sevilla es desde luego aleccionador ${ }^{36}$.

El vínculo directísimo que une las logias a su obediencia es otro de los componentes más llamativos de las relaciones exteriores masónicas. Las obediencias se comportan no sólo como lazo estructurador, también vigilan la regularidad de las logias, orientan y definen políticas de expansión y propaganda, facilitan contactos con personas o personalidades locales, etc. Por su parte, las logias consultan su obediencia, contribuyen financieramente, hacen ruegos de todo tipo (desde una ayuda material, «enchufes» o hasta un destino para un militar para evitar un destino en Cuba, etc.).

Estos continuos contactos se saldaban por una correspondencia exagerada que limitaba el axioma «logia libre, masón libre», mostrándonos que las relaciones podían ser amistosas, respetuosas, distantes o conflictivas. El GONE era bastante paternalista y exigente, el GOE era dirigista y centralizador, el GOIco era más liberal y el GCGI era la obediencia más ecléctica. A la sazón, las relaciones eran consecuentes. Las logias, en general, se plegaban a estas características; pero en los momentos importantes eran ellas las que marcaban la dirección de toda la Masonería, como sucedió con la fracasada unión nacional de 1888. Algo similar sucedió en 1923, cuando el GOE creó una estructura federativa que modificó los hábitos relacionales entre las logias y las obediencias. En suma, la sociedad masónica como reflejo propio de su concepto de sociabilidad, genera unas relaciones complejas y pluriformales que tienen una fuerte

36 Álvarez ReY, Leandro: Aproximación a un mito. Masonería y política en la Sevilla del siglo XX, Sevilla, Publicaciones del Ayuntamiento de Sevilla, 1996, pp. 33 y ss.

Hispania, LXIII/2, núm. 214 (2003) 523-550 
incidencia en la evolución misma de su sociabilidad, lo cual añade elementos cualitativos a su desarrollo o a su estancamiento.

Las logias masónicas practicaban la beneficencia como gesto supremo de una fraternización con todos los hombres del universo. Este principio está tan arraigado que es consustancial a la Masonería; por ello, algunas obediencias se inscribieron en el registro de asociaciones en 1887 como «sociedades de beneficencia». Así lo hizo el GONE del vizconde de Ros, declarándose una asociación humanitaria en «el ejercicio de la beneficencia pública y privada» ${ }^{37}$. Las modalidades de practicar la beneficencia están definidas en los reglamentos de las logias y, cuando no es una ayuda entre masones, la beneficencia masónica descubre al mundo profano un aspecto de la Masonería desconocido y da una imagen de sociedad humanitaria que redunda en su reputación.

Las desgracias naturales, las epidemias, las deficencias en la protección social y sanitaria de la España de finales del XIX hicieron que la beneficencia fuera una necesidad para gran parte de la sociedad española; la Masonería contribuyó siempre con sus pobres recursos materiales y humanos para ayudar al prójimo, cercano o lejano; y los archivos nos han dejado constancia de esta labor que nunca cesó. Si estos gestos son la exteriorización masónica por excelencia, el dar unos ejemplos nos ayudan a entender bajo otro prisma esta singular sociabilidad. Todas las logias de todas las regiones españolas reservaron fondos exclusivos (y que no formaban parte del tesoro propio de la logia), que se obtenían por medio del saco para la beneficencia (o Tronco de la Viuda) y donativos. Un masón, el limosnero, llevaba las cuentas de este fondo que se utilizaba únicamente para los casos que decidía el taller.

Los casos que avanzamos tuvieron lugar en Castilla y León a finales del siglo $\mathrm{XIX}^{38}$, pero son similares al resto de España. Las ayudas a otros masones (enfermedad, destierro, hospitalidad, etc.) son obligatorias y la solidaridad masónica fue constante. La beneficencia profana fue más variada: auxilios y ayudas a familias [logias Iris de Burgos (1873) y Luz de Medina (1888)], ayuda masónica nacional para las víctimas del temporal de León (1888). La logia Hijos de García Vao de Valladolid mandó una pequeña cantidad a los socorros contra la epidemia de gripe de 1890. Otro tanto hicieron las logias Reforma y Luz de León para las víctimas de las inundaciones en Andalucía en 1891, etc. No obstante, las logias contaban con pocos recursos y para obtener una ayuda suficiente solían abrir suscripciones con un éxito aleatorio. La concatenación de miserias y desgracias sociales movilizó a los masones que nunca explotaron su actitud; aunque en estas formas de beneficencia también podemos considerar una labor de secularización frente al monopolio de las órdenes religiosas. Vistas así las

37 FerRer Benimeli, José Antonio: La masonería española contemporánea. Desde 1868 hasta nuestros días, Madrid, Siglo XXI ed., 1980, vol. 2, pp. 11-12.

38 MARTin, Luis P.: La Masonería en Castilla y León, op. cit., pp. 124-128. Para Madrid, ver RANDOUYER, Françoise: «Beneficencia masónica: teoría y práctica», en FERRER BENIMELI, José Antonio (Ed.): Masonería, política y sociedad, op.cit., t. 2, pp. 501-507.

Hispania, LXIII/2, núm. 214 (2003) 523-550 
cosas, la beneficencia era una manera de acercar la masonería a los españoles, mostrándoles su concepto de fraternidad, de justicia social y sensibilidad frente a la desgracia ajena.

Las logias no sólo viven de cara al templo y aunque las manifestaciones puntuales sean limitadas, realizan una exteriorización muy distinta que el uso de la prensa y de la edición. En cualquiera de los casos y dependiendo del carácter de la logia, la exteriorización será más o menos discreta. No olvidemos que la masonería era una sociedad condenada y constantemente atacada por la Iglesia que la presentaba como demoníaca. Estas condiciones influyeron en las manifestaciones públicas o semi-públicas de los masones. Tampoco hay una gran variedad de manifestaciones, pudiendo limitarlas a dos: los banquetes masónicos y los entierros.

Las logias organizaban dos banquetes anuales que coinciden con los solsticios de invierno y de verano. También se organizaban banquetes con ocasión de un acontecimiento que marcaba, por ejemplo, la instalación. Estos banquetes tienen un ordenamiento ritual y su organización demanda un local discreto que acepte las condiciones de reserva, y además que no levante sospechas.

En algunas ocasiones, se intentaba que el propietario de la fonda o restaurante fuera masón. En el banquete que celebró la logia Aurora del Progreso de La Fuente de San Esteban (Salamanca) para celebrar su fundación en 1889, el dueño de la casa de comidas no era masón y el ritual se redujo a lo indispensable ${ }^{39}$. Para estos menesteres, la logia tiene un cargo de título explícito: maestro de banquetes. Existe una disposición de los comensales y sin excesivo protocolo, pero es un banquete normal y siempre entre masones. Sólo al final, los discursos toman un carácter masónico o político, si se trata de rememorar el aniversario de la $\mathrm{I}^{\mathrm{a}}$ República (el 11 de febrero) u otras conmemoraciones. Se entonan canciones masónicas y se baten baterías (palmas) en honor de los oradores y de la orden, etc. El banquete reviste en suma distintas dimensiones. Social y cultural, pero igualmente festiva. Barómetro de la cualidad burguesa de la sociabilidad masónica y en la España de entresiglos, el banquete tuvo una dimensión de reafirmación de los valores masónicos y políticos (identificación republicana, laicista...): En último término, todo banquete es una fiesta que refuerza la pertenencia en una sociedad por medio de una fraternización menos rígida que las tenidas.

En cuanto a los entierros, eran la manifestación pública más llamativa. Por un lado, los escasos cementerios civiles obligaban a los masones a realizarlos en el cementerio local, levantando la ira de la Iglesia y de sus feligreses. Por otro lado, daban lugar a una afirmación política de amplio alcance local. Los entierros fueron uno de las exteriorizaciones más importantes para la masonería española, sobre todo en el siglo XIX, porque también era una movilización contra la Iglesia.

39 Ver MARTín, Luis P.: La Masonería en Castilla y León, op. cit., p. 60. 
De hecho, los masones estaban condenados a vivir en este régimen y obligados a compartir el «espacio de los muertos» con todo el significado que tiene esta forzosa cohabitación. De aquí, las constantes peticiones de las logias para que las autoridades abran cementerios civiles, símbolo de una secularización en ciernes. Como esto no era corriente, los entierros masónicos se convertían en ocasiones en una lucha por parte de los clericales que defendían su monopolio mortuorio. Los testimonios que poseemos de los entierros son numerosos. Desde aquellos anónimos, como el entierro de un masón de la logia Fortaleza de Valladolid, hasta el entierro de un célebre krausista salamantino que se convirtió en un encuentro institucionista-masónico-republicano. En muy escasas ocasiones, las logias salieron a manifestarse en la calle, con los estandartes de la logia y los masones con sus insignias, bandas, etc. ${ }^{40}$. En otras regiones de España, los entierros masónicos producían idénticos sentimientos: la religión civil que era la Masonería no toleraba la intolerancia de la Iglesia en el último adiós de los hermanos de la logia a aquél que pasaba al oriente eterno. Dentro de este concepto podemos interpretar el interés que los masones daban al entierro, que precedía a una tenida fúnebre en honor del fallecido:

La historia ha retenido una serie de entierros públicos en los que participó la Masonería y que aparecieron en la prensa de la época. En el entierro del brigadier Escalante, héroe de «La Gloriosa», en agosto de 1869, hubo una manifestación pública del Gran Oriente de España. Otro entierro fue el del infante don Enrique de Borbón, muerto en duelo por el duque de Montpensier el 12 de marzo de 1870. El cuerpo del infante, liberal conocido y masón de la logia madrileña Los Puritanos, fue conducido por cuatro miembros del taller y con las insignias de Soberano Inspector del grado 33; pero el entierro no despertó una atención particular ${ }^{41}$. Los funerales del general Prim fueron de otro alcance. No sólo por la importancia del militar y también masón, sino por las incidencias que se produjeron en la basílica de Atocha y sobre todo por la polémica posterior, que relató con detalles el diario La República Ibérica ${ }^{42}$.

Estos entierros no fueron masónicos, sino que los masones se integraron en él provocando al clero que invocaba la profanación del templo cristiano. Los tres casos muestran la tolerancia gubernativa y la voluntad masónica de exteriorizarse; lo que se puede interpretar como una utilización del espacio público en acto de identificación colectiva que supera una identificación pública con la Masonería. Es un rasgo ideológico y militante de la sociabilidad masónica española y pone de relieve, por otro lado, la escasa penetración del masonismo en

40 EsteBAN DE VEGA, Mariano: «Católicos contra liberales: notas sobre el ambiente ideológico salmantino en la Restauración", Studia Historica (Historia contemporánea), Salamanca, vol. IV, 1986, p. 62.

41 RANDOUYER, Françoise: Les manifestations publiques et externes de la Franc-Maçonnerie vues par la presse espagnole (1868-1871), tesis de doctorado inédita, Universidad de Paris IV, 1981, pp. 116 y 127-128.

42 Acontecimiento relatado por PÉREZ GaLdós, Benito: Episodios nacionales [tomo III: Amadeo], en Obras completas, Madrid, Aguilar, 1970, pp. 1011-1012.

Hispania, LXIII/2, núm. 214 (2003) 523-550 
la sociedad, muy limitado a unos ambientes y círculos de sociabilidad que en ocasiones se superponían: logias masónicas/círculos republicanos/centros libre pensadores, etc.

La sociabilidad masónica, concentrada en una logia, es un paradigma de un modo de «estar en sociedad». La estructura social se acompaña de una compleja estructura cultural, filosófica y espiritual, a lo que hay que añadir una serie de «producciones» culturales y políticas que sirven de referente y de identificación. La logia masónica es un espacio social en el que confluyen varias formas de sociabilidad y esta pluralidad hace que su comprensión no sea fácil en comparación con otros modelos de sociabilidad. Es más, podemos preguntarnos si esta característica hace que no se le considere como un tipo de sociabilidad ${ }^{43}$, cuando a todas luces es una de las formas más genuinas que tuvo la España contemporánea.

No cabe duda que esta pluriformalidad produce dificultades de clasificación. ¿Se trata de una sociabilidad cultural o de beneficencia? ¿Es un sucedáneo de un partido político, etc.? Una de las causas de esta falta de clarificación viene de la Masonería misma que no siempre supo definirse, pero tampoco supo situarse en el espacio de las sociabilidades. Pero su originalidad es sólo aparente, como muestra su constitución, sus normativas, su desarrollo, su implantación social y geográfica, y su identifiación con los sectores de progreso. Sin entrar en estas consideraciones, la logia sufre de un déficit de análisis dentro de la necesaria visión transversal de las sociabilidades.

En estas páginas, la logia se ha visto estudiada bajo sus múltiples facetas y al considerarla como un modelo de sociabilidad no podemos olvidar que su cultura le imprime una personalidad aparte y hace, por esta razón, que sea pluriformal.

43 Con perplejidad, hemos constatado que en el estudio del Grupo de Estudios de Asociacionismo y Sociabilidad: España en sociedad. Las asociaciones a finales del siglo XIX, Cuenca, Ediciones de la Universidad de Castilla-La Mancha, 1998, no figura la voz «logia» en los conceptos de sociabilidad y ninguna referencia se hace de la sociabilidad masónica.

Hispania, LXIII/2, núm. 214 (2003) 523-550 